\title{
Editorial \\ Editorial: Mineral Nutrition of Fruit Trees
}

\author{
Marco Landi ${ }^{1,2, *(\mathbb{D})}$ and Ioannis E. Papadakis ${ }^{3, *}$ (D)
}

1 Department of Agriculture, Food and Environment, University of Pisa, Via del Borghetto 80, 56124 Pisa, Italy

2 CIRSEC - Centre for Climate Change Impact, University of Pisa, 56124 Pisa, Italy

3 Laboratory of Pomology, Department of Crop Science, School of Plant Sciences,

Agricultural University of Athens, Iera Odos 75, 11855 Athens, Greece

* Correspondence: marco.landi@unipi.it (M.L.); papadakis@aua.gr (I.E.P.)

Citation: Landi, M.; Papadakis, I.E. Editorial: Mineral Nutrition of Fruit Trees. Agronomy 2021, 11, 1315. https://doi.org/10.3390/ agronomy11071315

Received: 16 June 2021

Accepted: 22 June 2021

Published: 28 June 2021

Publisher's Note: MDPI stays neutral with regard to jurisdictional claims in published maps and institutional affiliations.

Copyright: (c) 2021 by the authors. Licensee MDPI, Basel, Switzerland. This article is an open access article distributed under the terms and conditions of the Creative Commons Attribution (CC BY) license (https:// creativecommons.org/licenses/by/ $4.0 /)$.
In the era of precision farming, the wise administration of water as well as the correct management of mineral nutrition is of outmost importance to reduce the agricultural inputs. Therefore, the effort to increase the nutrient use efficiency as well as to preserve the environment from redundant minerals, which can pose a serious risk for aquifer contamination, is essential [1]. The best practices aimed at the correct management of the mineral nutrition of fruit trees are also essential to promote fruit yield and quality; the topic deserves particular attention in the context of global change, which may seriously impact fruit tree management [2]. The Special Issue "Mineral Nutrition of Fruit Trees" is therefore timely and offers contributions that may help readers to focus on most recent aspects related to this trivial topic.

The Special Issue includes 19 research papers in which different aspects of fruit mineral nutrition have been investigated, with the help of the most updated technologies available in the sector of tree physiology and arboriculture, including metabolomics, transcriptomic, advanced photosynthesis as well as NMR investigations. Included papers are devoted to: (i) generate knowledge on the uptake, transport, accumulation and utilization of macroand micro-nutrients by different families and species of widely cultivated fruit trees including: apple [3], peach [4], naranjilla [5], kiwifruit [6], loquat [7], chestnut [8], almond [9] and avocado [10]; (ii) increase the knowledge on how abiotic (i.e., aridity [11,12] and salinity $[13,14])$ and biotic stress (i.e., Huanglongbing disease in citrus [15]), growing systems and/or cultural techniques (i.e., irrigation [4], soil fertilization [4,9], foliar fertilization [6] and grafting [12,16]) affect fruit trees' nutritional status and nutrient requirements; (iii) gain insight related to pre- and post-harvest physiological disorders attributable to mineral imbalance (e.g., boron excess in apple trees [17], macronutrient deficiency in fig [18] and bitter pit on apple fruits [19]; and (iv) propose new methods and models to correctly manage the fertilization of fruit tree species in the orchard or in pots [20,21].

In particular, Leitzke Betemps et al. [20] proposed a new Humboldtian diagnosis of peach tree (Prunus persica (L.) Batsch) nutrition using machine-learning and compositional methods in which the authors aimed at customizing nutrient diagnosis of peach trees at local scale. Lanauskas and colleagues [21] proposed the use of cattle horn shaving as a possible alternative of nitrogen for apple cultivation and they highlighted that horn shavings, acting as a nitrogen fertilizer, could be used for the management of apple trees, especially in organic orchards, where the use of synthetic fertilizers is prohibited.

The Special Issue also includes two literature surveys: Doyle and co-workers [22] reviewed the physiology of nitrogen and calcium nutrition in blueberry (Vaccinium sp.) with the attempt to summarize studies dealing with $\mathrm{N}$ acquisition, translocation and assimilation in determining $\mathrm{N}$-source preference in blueberry. In addition, modes of $\mathrm{Ca}$ acquisition and transport to the fruit, and various approaches to improve $\mathrm{Ca}$ concentration in fruit are discussed therein. Kalcsits et al. [23] proposed a literature update related to the recent achievements and new research opportunities for optimizing macronutrient availability, acquisition, and distribution for perennial fruit species. 
The Editors of the Special Issue are thankful to all the authors who gave their valuable contribution, which was essential for to the final outcome of the present Special Issue. The Editors are also thankful to the MDPI collaborators for their valuable support.

Author Contributions: M.L. original draft preparation; M.L. and I.E.P. writing-review and editing. All authors have read and agreed to the published version of the manuscript.

Funding: This research received no external funding.

Conflicts of Interest: The authors declare no conflict of interest.

\section{References}

1. Finger, R.; Swinton, S.M.; El Benni, N.; Achim, W. Precision Farming at the Nexus of Agricultural Production and the Environment. Annu. Rev. Resour. Econ. 2019, 11, 313. [CrossRef]

2. Carranca, C.; Brunetto, G.; Tagliavini, M. Nitrogen Nutrition of Fruit Trees to Reconcile Productivity and Environmental Concerns. Plants 2018, 7, 4. [CrossRef]

3. Mészáros, M.; Hnátková, H.; Čonka, P.; Náměstek, J. Linking Mineral Nutrition and Fruit Quality to Growth Intensity and Crop Load in Apple. Agronomy 2021, 11, 506. [CrossRef]

4. Casamali, B.; van Iersel, M.W.; Chavez, D.J. Nitrogen Partitioning in Young “Julyprince" Peach Trees Grown with Different Irrigation and Fertilization Practices in the Southeastern United States. Agronomy 2021, 11, 350. [CrossRef]

5. Viera, W.; Díaz, A.; Caicedo, C.; Suárez, A.; Vargas, Y. Key Agronomic Fertilization Practices That Influence Yield of Naranjilla (Solanum quitoense Lam.) in the Ecuadorian Amazon. Agronomy 2021, 11, 310. [CrossRef]

6. Sotiropoulos, T.; Voulgarakis, A.; Karaiskos, D.; Chatzistathis, T.; Manthos, I.; Dichala, O.; Mpountla, A. Foliar Calcium Fertilizers Impact on Several Fruit Quality Characteristics and Leaf and Fruit Nutritional Status of the 'Hayward' Kiwifruit Cultivar. Agronomy 2021, 11, 235. [CrossRef]

7. Ali, M.M.; Anwar, R.; Shafique, M.W.; Yousef, A.F.; Chen, F. Exogenous Application of Mg, Zn and B Influences Phyto-Nutritional Composition of Leaves and Fruits of Loquat (Eriobotrya japonica Lindl.). Agronomy 2021, 11, 224. [CrossRef]

8. Chatzistathis, T.; Papaioannou, E.; Giannakoula, A.; Papadakis, I.E. Zeolite and Vermiculite as Inorganic Soil Amendments Modify Shoot-Root Allocation, Mineral Nutrition, Photosystem II Activity and Gas Exchange Parameters of Chestnut (Castanea sativa Mill) Plants. Agronomy 2021, 11, 109. [CrossRef]

9. Sperling, O.; Karunakaran, R.; Yermiyahu, U. Precise Fertilization by a Mass-Balance of the Seasonal Changes in Nutrient Uptake by Almond Trees. Agronomy 2020, 10, 1277. [CrossRef]

10. Bonomelli, C.; Gil, P.M.; Schaffer, B. Effect of Soil Type on Calcium Absorption and Partitioning in Young Avocado (Persea americana Mill.) Trees. Agronomy 2019, 9, 837. [CrossRef]

11. Wang, J.; Chen, J.; Sharma, A.; Tao, S.; Zheng, B.; Landi, M.; Yuan, H.; Yan, D. Melatonin Stimulates Activities and Expression Level of Antioxidant Enzymes and Preserves Functionality of Photosynthetic Apparatus in Hickory Plants (Carya cathayensis Sarg.) under PEG-Promoted Drought. Agronomy 2019, 9, 702. [CrossRef]

12. Verdugo-Vásquez, N.; Gutiérrez-Gamboa, G.; Villalobos-Soublett, E.; Zurita-Silva, A. Effects of Rootstocks on Blade Nutritional Content of Two Minority Grapevine Varieties Cultivated under Hyper-Arid Conditions in Northern Chile. Agronomy 2021, 11, 327. [CrossRef]

13. Gil-Muñoz, F.; Delhomme, N.; Quiñones, A.; Naval, M.d.M.; Badenes, M.L.; García-Gil, M.R. Transcriptomic Analysis Reveals Salt Tolerance Mechanisms Present in Date-Plum Persimmon Rootstock (Diospyros lotus L.). Agronomy 2020, 10, 1703. [CrossRef]

14. Liu, C.; Zhao, X.; Yan, J.; Yuan, Z.; Gu, M. Effects of Salt Stress on Growth, Photosynthesis, and Mineral Nutrients of 18 Pomegranate (Punica granatum) Cultivars. Agronomy 2020, 10, 27. [CrossRef]

15. Shahzad, F.; Kadyampakeni, D.M.; Vashisth, T. Effect of Growing Media pH on Performance of Huanglongbing-Affected Young Citrus Trees. Agronomy 2021, 11, 439. [CrossRef]

16. Valverdi, N.A.; Cheng, L.; Kalcsits, L. Apple Scion and Rootstock Contribute to Nutrient Uptake and Partitioning under Different Belowground Environments. Agronomy 2019, 9, 415. [CrossRef]

17. Oikonomou, A.; Ladikou, E.-V.; Chatziperou, G.; Margaritopoulou, T.; Landi, M.; Sotiropoulos, T.; Araniti, F.; Papadakis, I.E. Boron Excess Imbalances Root/Shoot Allometry, Photosynthetic and Chlorophyll Fluorescence Parameters and Sugar Metabolism in Apple Plants. Agronomy 2019, 9, 731. [CrossRef]

18. Garza-Alonso, C.A.; Olivares-Sáenz, E.; Gutiérrez-Díez, A.; Vázquez-Alvarado, R.E.; López-Jiménez, A. Visual Symptoms, Vegetative Growth, and Mineral Concentration in Fig Tree (Ficus carica L.) Under Macronutrient Deficiencies. Agronomy 2019, 9, 787. [CrossRef]

19. Bonomelli, C.; Mogollón, R.; Tonetto de Freitas, S.; Zoffoli, J.P.; Contreras, C. Nutritional Relationships in Bitter Pit-Affected Fruit and the Feasibility of Vis-NIR Models to Determine Calcium Concentration in 'Fuji' Apples. Agronomy 2020, 10, 1476. [CrossRef]

20. Leitzke Betemps, D.; Vahl de Paula, B.; Parent, S.-É.; Galarça, S.P.; Mayer, N.A.; Marodin, G.A.B.; Rozane, D.E.; Natale, W.; Melo, G.W.B.; Parent, L.E.; et al. Humboldtian Diagnosis of Peach Tree (Prunus persica) Nutrition Using Machine-Learning and Compositional Methods. Agronomy 2020, 10, 900. [CrossRef] 
21. Lanauskas, J.; Uselis, N.; Buskienė, L.; Mažeika, R.; Staugaitis, G.; Kviklys, D. Cattle Horn Shavings: A Possible Nitrogen Source for Apple Trees. Agronomy 2021, 11, 540. [CrossRef]

22. Doyle, J.W.; Nambeesan, S.U.; Malladi, A. Physiology of Nitrogen and Calcium Nutrition in Blueberry (Vaccinium sp.). Agronomy 2021, 11, 765. [CrossRef]

23. Kalcsits, L.; Lotze, E.; Tagliavini, M.; Hannam, K.D.; Mimmo, T.; Neilsen, D.; Neilsen, G.; Atkinson, D.; Casagrande Biasuz, E.; Borruso, L.; et al. Recent Achievements and New Research Opportunities for Optimizing Macronutrient Availability, Acquisition, and Distribution for Perennial Fruit Crops. Agronomy 2020, 10, 1738. [CrossRef] 